\title{
The Contributing Role of Organizational-Based Self-Esteem to Organizational Commitment
}

\author{
Muh. Riefqy Faraelly Sam ${ }^{1, *}$, Elvita Bellani², Sri Wahyuni ${ }^{3}$ \\ ${ }^{I}$ Psychology Department, Medical Faculty, Hasanuddin University, Indonesia \\ 2 Psychology Department, Medical Faculty, Hasanuddin University, Indonesia \\ ${ }^{3}$ Psychology Department, Medical Faculty, Hasanuddin University, Indonesia \\ *Corresponding author. Email: riefqyfarel@gmail.com
}

\begin{abstract}
Organizational commitment has been linked to numerous desirable outcomes for the organization, including those in the public sector. During the covid-19 pandemic, where uncertainty increases and work changes are inevitable, organizational commitment becomes more significant. Thus, understanding the contributing factors to organizational commitment in civil servants is important. This present study investigates the contributing role of organizational-based self-esteem to organizational commitment. Three hundred forty civil servants in the Makassar government were randomly selected to participate in this study. The organizational-Based Self-Esteem scale and Meyer's Organizational Commitment scale were employed for data collection. The result shows that organizational-based self-esteem significantly contributes to normative commitment, affective commitment, and continuance commitment. This result indicates that employees' perception of themselves as unique, meaningful, and valuable to the organization contribute to their willingness to stay at the organization and devote themselves to the value and goal of the organization.
\end{abstract}

Keywords: Organizational-based self-esteem, organizational commitment

\section{INTRODUCTION}

Organizational commitment has been linked to numerous desirable outcomes for both personal and organization. Organizational commitment is a face orca $\mathrm{e}$ that binds individuals to remain in the organization by performing behavior consistent with the organization's beliefs, values, and goals [1]. High committed employees will be loyal and dedicate their resources to fulfilling their role in the organization [2], making them have better work performance [3]. Furthermore, high organizational commitment is negatively associated with numerous counterproductive behavior such as turnover [4]-[6] and absenteeism [2]

Self-consistency motivation [7] can be used to explain why individuals commit to their organization. Accordingly, people have an innate tendency to maintain their cognitive balance or consistency about themselves. Therefore, when people have a positive self-image, they will have an attitude and engage in behavior that will maintain or strengthen their positive image [8]. Thus, when individuals feel valued in an organization, they will commit to the organization. In contrast, employees whose low self-esteem will develop negative behavior towards organization values and goals.

This present study investigates the contributing role of Organizational-based self-esteem (OBSE) to organizational commitment. Previous research has found that OBSE contributes to organizational commitment [9]. Specifically in Indonesia, previous research conducted on a civil servant in Bayuwangi also suggests that OBSE leads to organizational commitment [10]. This study replicated the study by Indrayanti with civil servants in Makassar as the study population

\section{ORGANIZATIONAL-BASED SELF- ESTEEM AND ORGANIZATIONAL COMMITMENT}

According to Meyer, Organizational commitment represents the extent of employee willingness to remain a member organization [1]. Employees with high organizational commitment are willing to stay a 
member of the organization and behave in a way that will fulfill their role. The three different types of forces drive this willingness: affective commitment, which represents desire and identification to the goals and values of the organization; normative commitment, which represent perceived obligation to the organization; and continuance commitment, which means perceived cost and lack of alternatives should an employee leave the organization.

From a social consistency theory point of view [7], individuals aim to balance the cognitive processes they experience in a consistent way with what they believe. Thus, when an individual has a positive image of himself, he will try to engage in behavior that maintains or even strengthen their positive self-image. Therefore, when employees perceive themselves as necessary, capable, and valuable to the organization, they will try to preserve these beliefs in attitude and behaviors that result in organizational commitment.

Positive self-image to the organization can be conceptualized as organizational-based self-esteem, which represents the individual perception of his role as important, meaningful, and valuable to the organization [8]. It also means an individual's pride in the organization that he belongs. Individuals with a high level of OSE believe that some of their needs can be fulfilled from their role in the organization and thus identify themselves as members of the organization.

Given all that has been mentioned so far, we propose that OBSE is positively contributed to organizational commitment.

\section{METHOD}

\subsection{Samples and Procedures}

The questionnaire was distributed both online and offline to comply with government health protocol during pandemics. Sixteen participants filled the online questionnaire, and 324 filled the offline questionnaire, which makes it 340 participants in total.

Participants were selected via cluster sampling [11]. We chose these methods because we believe that the population is not entirely homogenous. At the beginning of the sampling process, we divide Makassar Government into three work units: secretariat, agency, and districts. Next, we randomly chose ten work unit that represents these types proportionately. Later, we distribute the questionnaire both online and offline to the employees who work at the chosen work unit.

\subsection{Measures}

\subsubsection{Organizational Commitment}

Organizational commitment was measured using an organizational commitment questionnaire (OCQ), developed by Allen \& Mayer [12] which has been adapted by Qurani [13]. This instrument was translated and adapted to suit the context of the research. There were 24 items which consisted of 8 items for each of the organization's commitment dimensions (i.e., affective commitment, continuance commitment, and normative commitment). Each item was presented in 5 options Likert scale. Previous studies owed that these items were valid and reliable [13]. Confirmatory factor analysis of the prior research shows RMSEA 0.06>0.08, which indicates a good fit and the reliability test show 0.879 , which indicates a reliable test.

\subsubsection{Organizational-based Self Esteem}

The scale of OBSE developed by Pierce et al. was used [14]. This scale comprises ten items displayed in five options of the Likert scale. The scale is valid and reliable. Confirmatory Factor Analysis yielded CFI $0.94>0.90$, GFI $0.94>0.90$, AGFI $(0.91>0.90$, TLI $0.92>0.90$, and RMSEA $0.07<0.08$ Reliability test using Cronbach alpha shows alpha 0.867 .

\section{RESULT}

\subsection{Descriptive Statistics}

Table 1 shows the descriptive statistics and intercorrelation between two variables.

\subsection{Hypothesis Testing}

\subsubsection{Contribution of OBSE to Affective Commitment}

Table 2. Result of linear regression of OBSE to affective commitment

\begin{tabular}{cccccc} 
& $\mathbf{R}$ & $\mathbf{R}^{2}$ & $\mathbf{F}$ & $\begin{array}{c}\text { Sig. } \\
\text { F }\end{array}$ & $\boldsymbol{\beta}$ \\
\hline OBSE & 0.385 & 0.148 & 58.694 & 0.000 & 0.294
\end{tabular}

Note: Dependent Variable = Affective Commitment, $\mathrm{N}=338, \beta=$ Unstandardized Beta Weight. 
As can be seen from Table 2, results of the linear regression indicated that there was a significant effect of OBSE to affective commitment, $\mathrm{F}(1,338)=58,694$, $\left.p<.001, \mathrm{R}^{2}=.148\right)$. This result also revealed that OBSE positively predicted affective commitment $(\beta=$ $.294, p<0.01)$.

Table 1. Descriptive Statistics

\begin{tabular}{|c|c|c|c|c|c|c|c|c|c|}
\hline$\overline{N o}$ & Variable & $\overline{\mathrm{M}}$ & SD & 1 & 2 & 3 & 4 & 5 & 6 \\
\hline 1. & Age & 40.77 & 8.802 & - & & & & & \\
\hline 2. & Length of work & 14.93 & 8.470 & $.838^{* *}$ & - & & & & \\
\hline 3. & $O B S E$ & 39.58 & 5.363 & .001 & .015 & - & & & \\
\hline 4. & Affective Commitment & 30.00 & 4.099 & .081 & .046 & $.385^{* *}$ & - & & \\
\hline 5. & Continance Commitment & 28.66 & 4.318 & .099 & .084 & .400 & $.321^{* *}$ & - & \\
\hline 6. & Normative Commitment & 28.92 & 4.029 & .020 & .033 & .432 & .365 & $.556^{* *}$ & - \\
\hline
\end{tabular}

Note: $\mathrm{N}=340, \mathrm{M}=$ Mean, $\mathrm{SD}=$ Standard Deviation, ${ }^{*} p<0.05, * * p<0.01$.

\subsubsection{Contribution of OBSE to Continuance Commitment}

Table 3. Result of linear regression OBSE to continuance commitment

\begin{tabular}{lccccc}
\hline & $\mathbf{R}$ & $\mathbf{R}^{2}$ & $\mathrm{~F}$ & Sig. F & $\boldsymbol{\beta}$ \\
\hline OBSE & 0.400 & 0.160 & 64.294 & 0.000 & 0.322
\end{tabular}

Note: Dependent Variable $=$ Continuance

Commitment, $\mathrm{N}=338, \beta=$ Unstandardized Beta Weight.

Table 3 shows the effect of OBSE on continuance commitment. The $\mathrm{R}^{2}$ value of .16 revealed that OBSE explained $16 \%$ variance in Continuance commitment with $\mathrm{F}(1,338)=64,294, p<.001$. These results showed that OBSE positively predict continuance commitment $(\beta=.322, p<0.01)$

\subsubsection{Contribution of OBSE to Normative Commitment}

Table 4. Result of linear regression OBSE to normative commitment

\begin{tabular}{lccccc}
\hline & $\mathbf{R}$ & $\mathbf{R}^{2}$ & $\mathbf{F}$ & Sig. F & $\beta$ \\
\hline OBSE & 0.432 & 0.187 & 77.644 & 0.000 & 0.322
\end{tabular}

Note: Dependent Variable $=$ Normative Commitment, $\mathrm{N}=338, \beta=$ Unstandardized Beta Weight.

Table 4 shows the effect of OBSE on normative commitment. The $\mathrm{R}^{2}$ value of .187 revealed that OBSE explained $16 \%$ variance in normative commitment with $\mathrm{F}(1,338)=77,644, p<.001$. These results showed that OBSE positively predict continuance commitment $(\beta=.322, p<0.01)$

\section{DISCUSSION}

Organization effectiveness is highly dependent on the human resources in the organization. However, not all human resources contribute equally to the attainment of organizational goals. Human resources who are committed to fulfilling their roles engage in behavior that is in line with the values and goals of the organization [1], [2]. Therefore, human resources in an organization must have organizational commitment.

This present study aims to investigate the contributing role of OBSE to the Organizational commitment of the civil servants of Makassar city government. Civil servants of the Makassar city government are responsible for providing services to approximately 1.5 million people [15]. Thus, it is very important that the civil servant of the Makassar city government is committed to fulfilling their role to serve the people of Makassar city.

This study shows a significant contribution from OBSE to the organizational commitment of civil servants in the Makassar city government. Furthermore, there is a positive relationship between the OBSE and organizational commitment which predicts that an increase in OBSE is predicted will be followed by an increase in affective commitment, continuance commitment, and normative commitment. The results of this study are in line with previous studies which also investigated the link 
between OBSE and organizational commitment [9], [16], [17], especially in civil servants [10]

These results support the predictions of the selfconsistency theory [7], which proposes that individuals tend to maintain or strengthen their selfimage. When individuals have a positive self-image, they will engage in attitudes and behaviors that support this positive self-image and vice versa. Individuals who have a high OBSE perceive that they are valuable and have unique contributions to attaining organizational goals. Therefore, individuals will engage with behaviors that align with this selfconcept. As a result, individuals develop organizational commitment

Furthermore, this study shows that OBSE contributes to affective commitment, normative commitment, and continuance commitment. As per the definition of this concept (see [1]), these results indicate that when an individual feels valuable to the organization, he is not only emotionally attached and identifies himself with the organization, he also feels that he must perform his role as well as possible, and also feels deprived of the source of his self-worth when he does not fulfil his role for the organization.

Furthermore, considering the importance of organizational commitment to the achievement of organizational goals, it will be worthwhile especially for Makassar City to consider increasing the OBSE of the employees. Piece and Gardner [8] improving suggest that OBSE can be improved by enhancing environmental work structure that can facilitate idea development and autonomy, positive appreciation from significant others such as co-workers and supervisors, and promote employees' self-efficacy development.

\section{CONCLUSION}

Using self-consistency motivation, the present study presents supporting evidence of the contributing role of OBSE to organizational commitment. Among three dimensions of organizational commitment, OBSE was found to positively contribute to all organizational commitment dimensions.

\section{REFERENCES}

[1] J. Meyer and L. Herscovitch, "Commitment in the workplace: Towards a general model," Human Resource Management Review, vol. 11, no. 3, pp. 299-326, 2001.

[2] F. Luthans, Organizational behavior: an evidence-based approach, 12th ed. New York: McGraw-Hill Companies, Inc., 2011.

[3] R. T. Mowday, L.W. Porter, and R., and R. Dubin, "Unit performance, situational factors, and employee attitudes in spatially separated work units," Organizational Behavior and Human Performance, vol. 12, no. 2, pp. 231248, 1974

[4] Sopiah, Perilaku organisasional. Yogyakarta: Andi, 2008.

[5] N. Sidharta and M. Margaretha, "Dampak Komitmen Organisasi dan Kepuasan Kerja Terhadap Turnover Intention: Studi Empiris Pada Karyawan Bagian Operator di Salah Satu Perusahaan Garment di Cimahi," Jurnal Manajemen, vol. 10, no. 2, pp. 129-142, 2011.

[6] Sumarto, "Meningkatkan Komitmen dan Kepuasan untuk Menyurutkan Niat Keluar," Jurnal Manajemen dan Kewirausahaan, vol. 11 , no. 2, 2009.

[7] A. K. Korman, "Toward a hypothesis of work behavior," Journal of Applied Psychology, no. 46, pp. 291-295, 1970.

[8] J. L. Peirce and D. G. Gardner, "Self-esteem within the work and organizational context: A review of the organization-based self-esteem literature," Journal of management, vol. 30, no. 5, pp. 591-622, 2004

[9] T. L. P. Tang and P. R. Gilbert, "Organizationbased self-esteem among mental health workers: A replication and extension.," Public Personnel Management, vol. 23, no. 1, pp. 127134, 1994.

[10] A. Indrayanto, "Pengaruh organizational-based self-esteem terhadap komitmen organisasional dan dampaknya pada kinerja pegawai," Modernisasi, vol. 8, no. 1, pp. 68-77, 2012.

[11] S. Siyoto and M. A. Sodik, Dasar Metodologi Penelitian. Yogyakarta: Literasi Media Publishing, 2015.

[12] N. J. Allen and J. P. Meyer, "The measurement and antecedents of affective, continuance and normative commitment to the organization," 
Journal of Occupational Psychology, no. 63, pp. 1-18, 1990.

[13] N. I. Qurani, "Kontribusi Persepsi Kepemimpinan Transformasional dan Kepuasan Kerja Terhadap Komitmen Organisasi pada Karyawan PT. X Makassar," Universitas Hasanuddin, 2018.

[14] J. L. Pierce, D. G. Gardner, L. L. Cummings, and R. B. Dunham, "Organization-based selfesteem: Construct definition measurement and validation," Academy of Management Journal, no. 32, pp. 622-648, 1989.

[15] "Data Penduduk: Salinan Salinan Data Penduduk Tahun 2020," DISDUKCAPIL KOTA
MAKASSAR.

https://dukcapil.makassar.go.id/datapenduduk/\#1611702020289-06982daf-d919

[16] C. Borycki, R. G. Thorn, and J. LeMaster, “Job satisfaction and organizational commitment: A comparison of United States and Mexico employees," International Journal of Commerce and Management, vol. 8, no. 3, pp. 7-25, 1998.

[17] N. A. Bowling, K. J. Eschleman, Q. Wang, C. Kirkendall, and G. Alarcon, "A meta-analysis of the predictors and consequences of organization-based self-esteem," Journal of Occupational and Organizational Psychology, vol. 83, no. 3, pp. 601-626, 2010. 